\title{
Non-executive Director Compensation and Financial Distress in China and South Africa: A Comparative Analysis in State-Owned Enterprises
}

Abraham Otim Emuron ( $\sim$ abraham@std.uestc.edu.cn )

University of Electronic Science and Technology of China https://orcid.org/0000-0003-4945-8365

Tian Yixiang

University of Electronic Science and Technology of China

Cephas Coffie

University of Electronic Science and Technology of China

\section{Research Article}

Keywords: China, South Africa, Non-executive directors, Financial distress, Compensation

Posted Date: February 4th, 2022

DOI: https://doi.org/10.21203/rs.3.rs-1319049/v1

License: (c) This work is licensed under a Creative Commons Attribution 4.0 International License.

Read Full License 


\section{Abstract}

The 21 st century has witnessed the rise of new and major economic regions that were initially overlooked by traditional economic superpowers. This study examines two such economies namely: China and South Africa. Certain attributes of the agency theory are examined. Henceforth, the research investigates the relationship between non-executive directors (NEDs) compensation and financial distress within listed firms. Emphasis is placed on the operations of listed state-owned enterprises (SOEs). NEDs play a vital role in reducing agency costs through the advising and monitoring of the firm's senior management, thereby aligning shareholder interests with those of senior management. This study therefore attempts to explore these aspects through the use of quantitative research methods and comparative analysis. The revised Altman Z-score model which incorporates features unique to emerging markets is used to measure financial distress. The findings indicate that in both countries financial distress will result in a reduction in NEDs pay.

\section{Introduction}

This paper attempts to examine the relationship between financial distress and NEDs compensation in two major developing economies namely South Africa and China. This study carries out a comparative analysis on how SOEs facing financial distress compensate NEDs. The study utilizes China and South Africa as these are the major economies within their respective continents, the study attempts to carry out a comparative analysis between these two countries to identify any similarities or differences that are unique to each of the samples obtained from the respective countries. Prior literature has proven that most SOEs are usually poorly managed and therefore not profitable with only a minority being successful in their objectives. There are also reports of conflict between the principal (state) and the agents (managers). In the corporate governance literature this is known as the agency problem.

The agency theory states that problems arise when one party (principal) hires another party (agent) using the basic assumption that agents are, self-seeking, rationally limited, and both the principals and agents have different goals and varying risk taking, hence misaligning the interests of the agent and principal (Payne \& Petrenko, 2019). This study focuses on NEDs as they play a crucial role in monitoring and advising management hence reducing the effects of the agency problem. NEDs align the interests of management with those of other stakeholders, in other words they provide a buffer that ensures that management does become self-seeking but rather complies with interests and wishes of the stakeholders. This is a very vital role played by NEDs as they are a direct link between the strategic decisions made by management and the interests of the principal (state, shareholders, etc.) who due to various reasons may not be able to directly monitor the activities of senior management. However, the supervisory capabilities of NEDs may be hampered due to the influence of senior management determining the compensation of NEDs. It's therefore important to investigate the relationship between NEDs compensation and a firm's performance (in this instance, a firm's financial distress). It is useful to ensure that management does not have direct influence on the decisions and monitoring capabilities of NEDs. As stated earlier, previous literature has noted the adverse performance of most state-owned 
enterprises therefore bringing up the question as to whether not NEDs are indeed performing their roles to the best of the abilities. Based on the agency theory recommendations, compensation rewarded to NEDs provides them an incentive to act in the interests of shareholders and hence improve corporate performance. Studies have investigated the relationship between and corporate performance and NEDs compensation. However, researchers are yet to investigate this association in relation to state-owned firms in emerging economies with a keen interest on firms facing financial distress. Other researchers in this this field have found that NEDs equity compensation improves firm value and performance. (Fich \& Shivdasani, 2005) and (Cordeiro et al., 2005; Hambrick and Jackson, 2000) respectively.

Henceforth this study tries to study the impact all financial distress within SOEs and how this affects and NED s compensation. NEDs play a vital role in reducing agency costs through the advising and monitoring of the firm senior management there by aligning shareholder interest with those of senior management. While financial distress is the inability of a firm to not be able to meet its contractual and financial obligations.

The remainder of the paper is organized as follows. Section two, consists of the literature review which describes the agency theory, NEDs and good corporate governance practices. Section three details the methodology. The fourth section highlights the results. Section five explores the discussions and conclusions.

\section{Literature Review}

\section{Agency Theory}

Agency theory is commonly used to understand and explain certain aspects in corporate governance, such as the coordination of managerial incentives, the oversight of boards of directors, and the management of top managers. There are various branches of the classic agency theory that have emerged to either support, challenge or add to the principal-agent relationship. Some of the more popular theories include the stewardship theory, principal-principal agency theory, and the behavioral agency theory (Payne \& Petrenko, 2019). With the behavioral theory receiving the most limelight. The behavioral agency theory focused on attributes such as the level of averseness to risk, motivation of the agent, fair compensation and time preference. The proponents of the behavioral theory Pepper \& Gore (2012); Sanders \& Carpenter (2003) and Wiseman \& Gomez-Mejia (1998), argue that the behavioral agency theory looks at the relationship between agency costs and agents' performance, while the classic agency theory emphasizes the relationship between the principal and the agent and the costs incurred by it. Next, the behavioral agent model finds a linear relationship between the agent's motivation and performance, while the agent model focuses on the principal's goals and the agency costs. Finally, the behavioral agency theory posits that the agent is a restrictively rational and risk averse person, maintaining a balance between internal and external interests, while the classic agency theory supports the notion that the agent is a logical and seeking compensation person. 
According to Castrillo \& Macho-Stadler (2021), the best design of incentives is a common problem in economic and social relations. A labor contract is often uncontractable, as a worker's (manager) decisions about his/her efforts are uncontractable, and his employer may need to provide incentives for his/her work. Management may be inclined to private gain by using some of the company's resources rather than maximizing the company's profits. These incentive issues arise because the parties involved, agents/managers, make decisions that affect other parties, principals/stakeholders, and are generally referred to as agency issues Castrillo \& Macho-Stadler (2021). Payne \& Petrenko (2019), state that the agency theory is one of the most important theoretical perspectives used in business and management studies. They posit that the agency theory puts forth that problems arise when one party (principal) hires another party (agent) using the basic assumption that agents are, self-seeking, rationally limited, and both the principals and agents have different goals and varying risk taking, hence misaligning the interests of the agent and principal. Table 1, further details the causes of the agency theory. In summary, Payne \& Petrenko (2019), insinuate that the values of the principal and agent are not fully optimized because these two contracting parties have different interests. As a consequence, agent costs are incurred due to this conflict of interest between principal and agent. The principal is the individual who actually owns the company, and the agent manages the company's business on behalf of the principal. Because two parties exist under the same company but have different or opposing goals and interests, a confrontation exists and this is called the agency problem.

Panda \& Leepsa (2017), state that the agency theory focuses on analyzing and reducing the problems that arise in enterprises through the separation of owners and managers. They further argue that the theory can help improvise different governance mechanisms for controlling the behavior of agents in jointly held enterprises. Corporate governance literature on the agency theory focusing on enterprises in USA found that most enterprises had a separation of ownership with the principals (stakeholders, shareholders, creditors, etc.) assigning the daily operations of their enterprises to agents (managers, NEDs, etc.). However, the question remained as to whether the agents were representing the principals' interests or their own (Berle \& Means, 1932; Jensen \& Meckling, 1976; Ross, 1973).

Smith (1937) predicted that if an enterprise is operated by an individual or group of individuals rather than the actual owner, it is unlikely to operate in the interests of the owner. Panda \& Leepsa (2017) argues that the agent could use the company's property for his own purposes, which could cause conflict between him and his agent. They further go on to state that while the principal of invests capital and takes risks to get financial benefits, the agent who manages the company is interested in avoiding danger and maximizing private profits. Both the agent and principal may have different risk assessments hence the issue of risk sharing creates an agency problem. Alchian \& Demsetz (1972) and Jensen \& Meckling (1976) look at the principal-agent relationship is a form of contract between principal and agent, and both parties are working for their own benefit, which will eventually lead to confrontation. With this in mind, the principal is forced to perform various monitoring activities to restrain the agent's behavior and manage agency costs. The agency relationship contracts help in the construction of ownership structures, incentive structures, labor markets, and so forth. 
Unfortunately, managers are more eager in maximizing their rewards. This self-seeking behavior is a rather rational and common human behavior, that is, humans are motivated to maximize their own needs (Sen, 1987; Williamson, 1985). The mismatch of interest between the principal and agents and the lack of proper oversight by the proliferation of weak ownership structures leads to confrontation known as agency cost. In an attempt to monitor managerial behavior and reduce the likelihood of agency costs, enterprises have resorted to hiring NEDs onto their board to help align the interests of management with that of enterprises stakeholders (Rosenstein \& Wyatt, 1990).

\section{INSERT TABLE 1}

\section{Non-Executive Directors (NEDs)}

An important task arises in the separation of ownership and control, where managers (agents) can abuse their authority within the company to maximize their wealth at the expense of shareholders (principal). The agency theory offers a possible remedy to deal with such an agency issue. Agency theory provides the use of external governance tools such as conditional compensation and NEDs monitoring to ensure that self-seeking managers are reigned in and have their interests aligned with those of the shareholders (Fama and Jensen, 1983; Jensen and Meckling, 1976). This remedy to the agency problem is based on the assumption that NEDs will work in the interest of the principals in safeguarding their stake within the enterprise. However, existing literature has proven that this assumption does not hold at all times and NEDs can get compromised and not carry out their monitoring duties as expected (Brick, Palmon, and Wald, 2006; Walsh and Seward, 1990). There has been evidence of cronyism perpetuated between enterprise managers and NEDs. Issues of NEDs compensation being approved and awarded by management has also led to further enquiry as to whether NEDs are in a suitable position to oversee and monitor the actions of management effectively. Hence, this research attempts to investigate the relationship between NEDs compensation and a firm's financial distress.

In theory, Coles et. al. (2001) states that the main duty of NEDs is to monitor senior management and also to act as advisors to the chief executive officers (CEOs). According to Mookherjee \& Reichelstein, 2001 and Leung \& Adithipyangkul, 2018, the NEDs plays the role of delegating the task of running the company to the senior management. They further elaborate that through the use of incentive rewards/compensation, it is possible to align the interests of the involved agents (NEDs and senior management) with the interests of the principal (shareholders). These incentive rewards are used to motivate second-tier agents (senior management) to run the company, as well as incentivize first-tier agents (NEDs) to perform supervisory and monitoring tasks. 
Udin, Khan \& Javid (2017), emphasize the importance of corporate governance by stating that the success of an enterprise relies on its proper implementation of corporate governance practices. They argue that all-round policy makers and researchers generally agree that a sound system of corporate governance helps improve a company's financial performance and attract investment from domestic and foreign investors McKinsey (2000).

(Sun et al. 2014) define financial distress as the company's inability to meet its debt requirements. That is, the company experiences bankruptcy, liquidation, or other forms of disposition and distribution of its assets. Businesses facing financial hardships suffer huge losses, so being able to predict economic hardship before it happens is paramount to business success. Corporate debt tends to adversely affect all stakeholders, including employees, shareholders, managers, investors, creditors and NEDs (Chen and Merville 1999).

Financial distress results in both the deterioration of a company's performance and management. Financial distress is the state wherein the company has insufficient cash flows to meet its debt obligations (Wruck, 1990). Whitaker (1999) argues that financial difficulties could occur when the company's current debt exceeds cash inflows. However, financial difficulties are not limited to the company not paying off its debt, and a series of other incidents can occur before the company defaults. He further explains that the effects of financial distress can be seen in advance by observing a decrease in company value before the actual default of the company. Chen (1983), on the other hand defines financial distress as the state of power revenue, delayed debts, and the shortage of cash flows.

A number of models have been developed to predict financial distress within firms. (Beaver 1966), was among the first pioneers in this field by using a univariate discriminant analysis to compare the ratios of failed and non-failed firms. This model was later improved by Altman (1968), by using multiple discriminant analysis (MDA) to identify a group of distress prediction ratios. The MDA has proven to be robust in its prediction of financial distress and has been adopted by numerous researchers (Agarwal \& Taffler, 2007; Deakin 1972; Grice \& Ingram, 2001). For purposes of this research the Altman Z-score is used in predicting the financial distress in listed SOEs both in China and South Africa. Recent studies also prove that the original Altman Z-score is still potent in predicting financial distress (e.g., llahi et al., 2015; Li \& Rahgozar, 2012; Rim \& Roy, 2014). This research utilizes a slightly modified Altman Z-score that caters for emerging economies.

\section{Hypothesis Development}

It has been established that the role of NEDs is to monitor and advise senior management as they are less likely to be influenced by the same individuals they supervise. However, certain incidences arise where such independence can be compromised such as when their compensation is determined by top management. We attempt to investigate how SOEs facing distress in China and South Africa compensate their NEDs. We develop a comparative analysis between the two countries using the panel pooled mean 
(PMG)/ autoregressive distributed lag (ARDL) model in the estimation of the relationship between nonexecutive director compensation and financial distress in China and South Africa. Henceforth, this study posits the hypothesis that firms facing financial distress reduce non-executive compensation.

\section{Methodology}

\section{Sample Selection}

For the China related analysis, data is obtained from the China Stock Market. Due to infrequent trading of the B-shares and their relatively small number, we utilize the A-shares traded on the Shanghai Stock Exchange (SHSE) and the Shenzhen Stock Exchange (SZSE) during the period 2005-2018. The following firms are excluded from the sample: (1) firms in the financial sector; (2) delisted firms, ST (Special Treatment) firms; and (3) firms with missing financial information. The data is based on annual observations and taken from the China Stock Market and Accounting Research (CSMAR) and Wind database. For the South African related analysis, the data is hand collected from the respective annual statements for each company. The sample covers a period from 2005 to 2018 . Data is manually collected of SOEs listed in Schedule 2 which is published by the government of South Africa on an annual basis. All the entities, including the subsidiary companies are included in the study.

\section{INSERT TABLE 2}

\section{Model Specification}

Similar to existing studies, we employ the panel pooled mean (PMG)/ autoregressive distributed lag (ARDL) model in the estimation of the relationship between non-executive director compensation and financial distress in China and South Africa. However, to provide robustness for the model, we have added other variables which are theoretically proven to affect non-executive director compensation. Consequently, the model is given as stated in Equation 1;

$$
N D P_{i t}=\beta_{0}+\beta_{1} F D S_{i t}+\beta_{2} R O A_{i t}+\beta_{3} S A G_{i t}+\beta_{4} L E V_{i t}+\beta_{5} F S I Z E_{i t}+\delta_{i t}
$$

Where NDP stands for the compensation of NEDs of the SOEs in China and South Africa. FDS stands for financial distress conditions of the enterprises in these countries, ROA stands for return on asset, SAG represents the sales growth of the enterprises, LEV stands for leverage, and FSIZE stand for the size of the enterprises. Further, $\delta$ stands for the error correction term of the model. However, to ensure that the estimation of the model is robust, accurate, and free from the possibility of misleading interpretations, the base model is log-transformed into Equation 2. 


$$
\operatorname{InNDP}_{i t}=\beta_{0}+\beta_{1} \operatorname{InFDS}_{i t}+\beta_{2} \operatorname{InROA}_{i t}+\beta_{3} \operatorname{InSAG}_{i t}+\beta_{4} \operatorname{InLEV}_{i t}+\beta_{5} \operatorname{InFSIZE}_{i t}+\delta_{i t}
$$

Further, to ensure that the estimation of the model produces robust output, the following econometric processes. First, descriptive analysis is performed to understand the distribution of the data, next, the existence or the absence of issues of multicollinearity within the study variables are assessed, further, because the companies selected for the study belong to the same ownership structure, there could be issues of cross dependencies and thus we assess that phenomenon. After, we conduct the test of homogeneity to ensure that the companies used in the panel are independent from each other. Again, the unit root test is performed to find the stationarity of the variables. Finally, the model is estimated alongside the causality test and the robustness test.

\section{Results}

\section{Descriptive statistics and multicollinearity checks}

The results presented in Table 3 provides summary of the descriptive statistics of the variables employed in the various panels. Per the China panel, non-executive director pay (NDP) shows average of 8.64 and a standard deviation of 1.55. Further, financial distress (FDS), return on asset (ROA), sales growth (SAG), leverage (LEV), and firm size (FSIZE) show 5.76(0.87), 12.86(1.76), 3.03(0.91), 5.87(0.70), and 4.34 (0.56) respective values for mean and standard deviation. Per the South Africa panel, NDP shows an average of 6.98 and a standard deviation of 1.21. This establishes that the NDP in China is relatively higher than the NDP in South Africa. Further, financial distress (FDS), return on asset (ROA), sales growth (SAG), leverage (LEV), and firm size (FSIZE) show 2.11(1.05), 9.54(0.89), 2.01(1.87), 3.85(0.87), and 2.65(0.43) respectively. The values reported provides evidence to the difference in the size of these countries. Concerning the skewness of the data, the China panel shows that all the data are negatively skewed showing a longer left tail. Similarly, the panel for South Africa also shows negative skewness for all the variables. However, on the overall data, LEV and FSIZE show positive skewness. Further, the test for kurtosis reveals that, all the variables for the China panel are less than 3.00. This indicates that the distribution is platykurtic producing fewer outliers. Per the south Africa panel, all the variables show platykurtic distribution except NDP which is slightly above 3.00. This suggests that all the variables have limited outliers. Again, the overall panel reports values of more than 3.00 for LEV and FSIZE. Finally, the Jarque-Bera (JB) test for goodness-of-fit shows that, all the panels have distributions which are not normally distributed. Therefore, the variables provide adequate variability for the model estimation.

\section{INSERT TABLE}


Further, we estimated the Pearson correlation matrix to examine the interrelationship between the various variables employed in the panels. Table 4 presents summary of the result. Accordingly, value above 0.5 indicate potential for multicollinearity issues. Per the China panel, the relationship between NDP and all the variables show values below 0.5 except for the relationship between NDP and SAG which is 0.52 . The relationship between FDS, ROA, SAG, LEV, and FSIZE and all the other variables show values below 0.05 . Further, the South Africa panel indicate that the interrelationship between the various variables have values below 0.5 . Finally, per the overall panel, all the relationships show values less than 0.5 . To further test for the absence of multicollinearity, we use the tolerance and the variance factor inflator (VIF). Accordingly, the values reported of less than 10.00 indicate the absence of multicollinearity between the variables.

\section{INSERT TABLE 4}

Given the possibility of issues of cross-sectional dependence which may arise as a result of similar industry practices, government practices, or form of business ownership, we estimate the cross-sectional dependence test to eliminate this possibility. Accordingly, the results presented per Table 5 indicates that there is no issue of cross-sectional dependencies in the panels. Therefore, the differences in the number of businesses included in each panel has no cross-sectional effect on the panels leading to the acceptance of the null hypothesis of no cross-sectional dependence.

\section{INSERT TABLE}

The test for homogeneity helps to establish whether the panels have similar distribution or otherwise. This is necessary because panels with similar distribution could produce bias estimates and also affect the interpretation of the results. Accordingly, the results presented in Table 6 is a summary of the homogeneity test for the China, South Africa, and the overall panels respectively. The results from the test shows that there exists no issue of homogeneity in the panels. Consequently, the null hypothesis of no homogeneity cannot be rejected.

\section{INSERT TABLE 6}

After the establishment of no cross-sectional dependence, no issue of homogeneity in the panel, next we check for the integration properties of the variables employed in the panels. Table 7 provides a summary of the ADF panel unit root test results. Per the China panel, only SAG and FSIZE variables are integrated at level-form and first-order. Thus, all the other variables are non-stationary at the level-form but become stationary when integrated at the first-order. Further, the South Africa panel also has the NDP and the FSIZE variables integrated at the level-form and at the first-order. However, the other variables are only stationary at the first-order. Finally, the overall panel has all the variables non-stationary at the level-form. This suggests that a shift in time has no significant effect on the stationarity of the variables employed in the panel. Thus, in the short-run and the long-run, the estimates of the variables would be applicable. 


\section{INSERT TABLE 7}

Next, we estimate the pooled mean group (PMG)/ Autoregressive distributed lag (ARDL) model to estimate the relationship between NDP and FDS, ROA, SAG, LEV, and FSIZE. The coefficients and the probability values reported for the variables are used for the interpretations. Table 8 provides a summary of the PMG/ARDL result. Per the China panel, the result shows that FDS has a negative significant relationship with NDP. This is supported by a coefficient of -0.34 and a probability value of $0.00 \mathrm{a}$. Thus, a unit increase in financial distress of SOEs in China leads to a -0.05 decrease in NEDs compensations. Comparatively with the case of South Africa, a unit increase in the financial distress of SOEs leads to a decrease of -0.32 in NEDs compensations. This is supported by a statistically significant value of $-0.32(0.00 \mathrm{a})$. Therefore, although there exists a negative relationship between financial distress and NEDs compensation in these two countries, NEDs in South Africa are likely suffer huge reduction in compensation compared to those in China. Overall, the result indicates a negative relationship between NEDs compensation and financial distress in these two countries. On the relationship between NEDs compensation and return on asset in these countries, the panels in China and South Africa both establishes a positive significant relationship between NDP and ROA with statistically significant values of $0.07(0.03 a)$ and $0.09(0.00 a)$ respectively. However, there is a high likelihood that NEDs in South Africa would receive higher compensation for improved ROA than those in China. Overall, the result shows a positive and significant relationship between NDP and ROA in these two countries. Further, per the relationship between sales growth and NEDs compensation in these countries, both China and South Africa panels show positive significant relationships with statistically significant values of $0.12(0.01)$ and $0.03(0.04)$ respectively. This suggests that although an increase in sales increases the compensation of NEDs, those in China are likely to receive higher compensation than those in South Africa. However, overall, the relationship between sales growth and NEDs compensation is statistically insignificant when both countries are combined in a single panel. Again, the relationship between leverage and NEDs compensation shows statistically insignificant relationship for all the three distinct panels. Finally, concerning the relationship between firm size and NEDs compensation, all the three panels show statistically significant values of $0.04(0.02 a), 0.11(0.03 a)$, and $0.21(0.00 a)$ respectively. This indicates that the bigger the size of the firm, the higher the NED compensation. The error correction term (ECT) measures the speed of adjustment towards the long-run equilibrium. Per the results, the values of $-0.31,-0.53$, and -0.20 respectively fall within the accepted speed range of $-1-0$. Finally, the Hausman test values concludes that the model is good for the estimation of the pooling coefficients in the model, while the CD-test results reject the null hypothesis of cross-sectional dependence.

\section{INSERT TABLE 8}

Further, to establish the robustness of the of the PMG/ARDL, the CCEPMG/CS-ARDL and the MG estimators are employed. This helps in resolving potential issues of strong residual cross-sectional dependence. Table 9 provides a summary of the output. Per the short-run and the long-run results depicted in table 8 , there seems to be significance levels between the variables are evidenced not to differ 
significantly. However, the increased in the long-run elasticities is because the CCEPMG/CS-ARDL theoretically provides larger elasticities than the MG.

\section{INSERT TABLE 9}

Finally, Table 10 provides a summary result of the causality between the variables. Although the PMG/ARDL has established a long-run relationship between the variables, there is the need to understand the path of the causal relationship between the variables. Therefore, we employ the Dumitrescu-Hurlin Panel causality test to estimate the causal relationship between the variables. Per the results in table 10, the panel pertaining to China shows that there exists a bidirectional causal relationship between FDS and NDP and FSIZE and NDP. Further, there exist a unidirectional causal relationship between NDP and ROA. Per the South Africa Panel, a bidirectional causal relationship is seen to exist between FDS and NDP. However, a unidirectional causal relationship exists between NDP and ROA. Finally, the overall model shows that there exists a unidirectional causal relationship between FDS and NDP as well as NDP and ROA.

\section{INSERT TABLE 10}

\section{Conclusion And Discussion}

This study aims to examine the relationship between of NEDs compensation and financial distress within listed state-owned enterprises in China and South Africa. This study provides evidence that South African SOEs facing financial distress tend to reduce NEDs compensation. This is line with previous literature. On the contrary, SOEs in South Africa with good financial health tend to increase their NEDs compensation. This result is in tandem with good corporate governance policies as stipulated by the Kings Act (Emuron \& Yixiang, 2020). A similar result is also obtained in the case of Chinese SOEs. This is denoted by the negative and significant value of $-0.34(0.001)$ when a firm is in financial. South African NEDs suffer a higher reduction in compensation as compared to their Chinese counterparts

The evidence presented further explains how the size, performance and leverage affect NEDs compensation in SOEs when faced with financial distress. There is however a non-significant result in the case of sales growth. The comparative analysis indicates that firms in both countries tend to reduce NEDs compensation when facing financial distress. The results obtained provide valuable insights as to how listed state-owned enterprise compensate their NEDs when faced with financial distress. This study makes a number of significant contributions to the already existing corporate governance literature both in South Africa and China. It fills a gap in the limited literature on NEDs compensation. From the best of our understanding, this is the first study that attempts to examine the relationship between NEDs compensation and financial distress in emerging economies.

This research does, however, have some limitations as it does not take into account private and publicly listed (non-state-owned) firms facing financial distress and how they compensate their NEDs. These 
issues raised provide a potential area for further research into the compensation of NEDs and the importance of the agency theory in formulating corporate governance policies.

\section{Declarations}

\section{Conflict of interest}

On behalf of all authors, the corresponding author states that there is no conflict of interest.

\section{References}

Adithipyangkul, P. \& Leung, T.Y. (2018). Incentive pay for non-executive directors: The direct and interaction effects on firm performance. Asia Pacific Journal of Management, 35, 943-964.

Agarwal, V., \& Richard, J.T. (2007). Twenty-five years of the Taffler Z-score model: Does it really have predictive ability? Accounting and Business Research, 37, 285-300.

Alchian, A., \& Demsetz, H. (1972). Production, information costs, and economic organization. The American Economic Review, 62(5) 777-795.

Altman, E.I. (1968). Financial ratios, discriminant analysis and the prediction of corporate bankruptcy. The Journal of Finance, 23, 589-609.

Beaver, W.H. (1966). Financial ratios as predictors of failure. Journal of Accounting Research, 4, 71-111.

Berle, A., \& Means, G. (1932). The Modern Corporation and Private Property. New York: Macmillan.

Brick, l., Palmon, O., \& Wald, J. (200). CEO compensation, director compensation, and firm performance: Evidence of cronyism? Journal of Corporate Finance, 12, 403-423.

Chen, G.M., \& Merville, L.J. (1999). An analysis of the underreported magnitude of the total indirect costs of financial distress. Review of Quantitative Finance and Accounting, 13, 277-93.

Chen, Z. (1983). A Study of Financial Distress Model by Using Financial Ratios. Master's thesis, National Chengchi University, Taipei, Taiwan.

Wruck, K.H. (1990). Financial distress, reorganization, and organizational efficiency. Journal of Financial Economics, 27, 419-44.

Coles, J.W., McWilliams, V.B., \& Sen, N. (2001). An examination of the relationship of governance mechanisms to performance. Journal of Management, 27, 23-50.

Cordeiro, J.J., Veliyath, R., \& Neubaum, D.O. (2005). Incentives for monitors: Director stock-based compensation and firm performance. Journal of Applied Business Research, 21(2), 81-90. 
Deakin, E.B. (1972). A discriminant analysis of predictors of business failure. Journal of Accounting Research, 10, 167-79.

Emuron, A.S.O., \& Tian, Y.X. (2020). Financial distress and non-executive director compensation: Evidence from state owned enterprises in South Africa post King III. African Development Review, 32, 228-239.

Fama, E., \& Jensen, M. (1983). Separation of ownership and control. Journal of Law and Economics, 26(2), 301-325.

Fich, E., \& Shivdasani, A. (2005). The impact of stock-option compensation for outside directors on firm Value. Journal of Business, 78(6) 2229-2254.

Tyge, G.P., \& Oleg V.P. (2019). Agency theory in business and management research. Oxford Research Encyclopedia of Business and Management, doi:10.1093/acrefore/9780190224851.013.5.

Grice, J.S., \& Robert W.I. (2001). Tests of the generalizability of Altman's bankruptcy prediction model. Journal of Business Research, 54, 53-61.

Hambrick, D.C., \& Jackson, E.M. (2000). Outside directors with a stake: The linchpin in improving governance. California Management Review, 42(2), 108-127.

Ilahi, I., Raja, A.J., Sibtain K.N.I., \& Muhammad, S.L. (2015). Financial performance analysis of Pakistan banking sector using Altman score model of corporate bankruptcy. Applied Research Journal, 1, 33-40.

Macho-Stadler, I., \& Pérez-Castrillo, D. (2021). Agency theory meets matching theory. SERIEs, 12, 1-33.

Jensen, M., \& Meckling, W. (1976). Theory of the firm: Managerial behavior, agency costs, and ownership structure. Journal of Financial Economics, 30), 305-360.

$\mathrm{Li}$, J., \& Reza, R. (2012). Application of the Z-score model with consideration of total assets volatility in predicting corporate financial failures from 2000-2010. Journal of Accounting and Finance, 12, 11-19.

McKinsey. (2002). Global Investor Opinion Survey on Corporate Governance. McKinsey and Company, OECD.

Mookherjee, D., \& Reichelstein, S. (2001). Incentives and coordination in hierarchies. Advances in Theoretical Economics, 1(1), 1-36.

Pepper, A., \& Gore, J. (2012). Behavioral agency theory new foundations for theorizing about executive compensation. Journal of Management, 41(4), 1045-1068.

Rim, E.K., \& Al Beaïno R. (2014). Classifying manufacturing firms in Lebanon: An application of Altman's model. Procedia-Social and Behavioral Sciences, 109: 11-18. 
Rosenstein, S., \& Wyatt, J.G. (1990). Outside directors, board independence and shareholder wealth, Journal of Financial Economics, 26(2), 175-191.

Ross, S. (1973). The economic theory of agency: The principal's problem. American Economic Review, 63(2), 134-139.

Sanders, G., \& Carpenter, M. (2003). A behavioral agency theory perspective on stock repurchase program announcements. Academy of Management Journal, 46(3), 160-178.

Sen, A. (1987). The Standard of Living. Cambridge: Cambridge University Press.

Shapiro, S. (2005). Agency theory. Annual Review Sociology, 31(1), 263-284.

Smith, A. (1937). The Wealth of Nations. New York: Modern library.

Sun, J., Hui L., Qing-Hua H., \& Kai-Yu H. (2014). Predicting financial distress and corporate failure: A review from the state-of-the-art definitions, modeling, sampling, and featuring approaches. KnowledgeBased Systems, 57, 41-56.

Udin, S., Khan, M.A., \& Javid, A.Y. (2017). The effects of ownership structure on likelihood of financial distress: An empirical evidence. Corporate Governance, 17(4), 589-612.

Walsh, J.P., \& Seward, J.K. (1990). On the efficiency of internal and external corporate control mechanisms. Academy of Management Review, 15(3), 421-458.

Whitaker, R.B. (1999). The early stages of financial distress. Journal of Economics and Finance, 23, 12332.

Williamson, O.E. (1985). The economic institutions of capitalism. Corporate finance and corporate governance. Journal of Finance, 43(3), 567-591.

Wiseman, R., \& Gomez-Mejia, L. (1998). A behavioral agency model of managerial risk taking. Academy of Management Review, 23(1), 133-153.

\section{Tables}

Table 2. Different causes of the Agency problem 
Separation of ownership from control

Risk Preference

Duration of

Involvement

Limited Earnings

Decision-making

Information

Asymmetry

Moral Hazard

Retention of

Earnings
The separation of ownership from control in the large organizations leads to loss of proper monitoring by the owners on the managers, where managers use the business property for their private purpose to maximize their welfare.

The parties involved in the organizations are having different risk perceptions and struggle to reconcile with their decisions. This conflict arises between the owners and managers and owners and creditors.

The managers work for the organizations for a limited period, whereas the owners are the inseparable part of the firms. Hence, the agents try to maximize their benefit within their limited stay and then flow to another firm.

Both the managers and creditors of the firm are the significant stakeholders of the firm, but they are having only limited earnings as managers are concerned for their compensation, while creditors look for the interest amount only.

Mostly, the majority shareholders take the decision in the firms due to high voting rights, while the minority shareholders only follow it.

Managers look after the firm and are aware about all the information related to the business, while owners depend upon the managers to get the information. So the information may not reach to the owners exactly in the same manner.

Managers work for the owners in good faith, where the owners utilize their knowledge and skill in the risky projects, which the managers are not aware of the risk attached to the investment decision for which they suffer.

The majority owners take the decision to retain the earnings of the firm for future profitable risky projects instead of distributing the profits as dividends to all the shareholders. Due to which the minority shareholders lose their earnings.

Source: Panda and Leepsa (2017)

Table 2 Source and description of data 


\begin{tabular}{|c|c|c|c|}
\hline Variables & Abbreviation & Description & Source* \\
\hline NEDPAY & NDP & Non-executive director compensation & CSMAR \\
\hline Financial distress & FDS & Companies in financial distress & CSMAR \\
\hline Return on Asset & ROA & Annual Return on Asset & Wind Database \\
\hline Sales growth & SAG & Annual percentage of sales growth & Wind Database \\
\hline Leverage & LEV & Annual leverage & Wind Database \\
\hline Firm Size & FSIZE & The size of the firms & Wind Database \\
\hline
\end{tabular}

*Source: Authors Construct

Table 3 Descriptive Statistics

\begin{tabular}{cccccc}
\hline Variables & Mean & Std. Dev & Skewness & Kurtosis & JB \\
\hline INDP & 8.64 & 1.55 & -0.98 & 2.88 & $89.45^{\mathrm{a}}$ \\
lFDS & 5.76 & 0.87 & -0.67 & 1.99 & $77.65^{\mathrm{a}}$ \\
IROA & 12.86 & 1.76 & -0.45 & 2.80 & $63.40^{\mathrm{a}}$ \\
ISAG & 3.03 & 0.91 & -0.88 & 2.98 & $103.56^{\mathrm{a}}$ \\
ILEV & 5.87 & 0.70 & -0.91 & 1.69 & $98.43^{\mathrm{a}}$ \\
IFSIZE & 4.34 & 0.56 & -1.01 & 2.76 & $67.98^{\mathrm{a}}$ \\
\hline \multicolumn{6}{c}{ South Africa } \\
\hline INDP & 6.98 & 1.21 & -0.77 & 3.01 & $110.11^{\mathrm{a}}$ \\
IFDS & 2.11 & 1.05 & -0.32 & 2.04 & $88.98^{\mathrm{a}}$ \\
IROA & 9.54 & 0.89 & -0.90 & 2.34 & $161.12^{\mathrm{a}}$ \\
ISAG & 2.01 & 1.87 & -0.75 & 1.86 & $78.89^{\mathrm{a}}$ \\
ILEV & 3.85 & 0.87 & -1.11 & 2.87 & $69.22^{\mathrm{a}}$ \\
IFSIZE & 2.65 & 0.43 & -1.34 & 2.11 & $91.87^{\mathrm{a}}$ \\
\hline \multicolumn{7}{c}{ Overall } \\
\hline INDP & 9.12 & 1.68 & -0.93 & 2.12 & $101.23^{\mathrm{a}}$ \\
lFDS & 6.31 & 1.79 & -0.45 & 2.45 & $98.98^{\mathrm{a}}$ \\
IROA & 10.23 & 0.98 & -0.56 & 1.98 & $199.23^{\mathrm{a}}$ \\
ISAG & 4.34 & 1.53 & -0.83 & 2.99 & $150.23^{\mathrm{a}}$ \\
ILEV & 5.23 & 1.09 & 0.94 & 3.23 & $231.22^{\mathrm{a}}$ \\
IFSIZE & 3.12 & 1.23 & 0.82 & 3.21 & $121.01^{\mathrm{a}}$ \\
\hline
\end{tabular}

Note: ${ }^{a}$ represents statistical significance at $0.05 \%$

Table 4 Pearson Correlation analysis 


\begin{tabular}{cccccccccc}
\hline Panel & Variables & LNDP & LFDS & LROA & LSAG & LEV & LFSIZE & Tolerance & VIF \\
\hline China & INDP & 0 & & & & & & & \\
& IFDS & $0.45^{\mathrm{a}}$ & 0 & & & & & 2.34 & 1.07 \\
& IROA & $0.32^{\mathrm{a}}$ & $0.44^{\mathrm{b}}$ & 0 & & & & 1.92 & 3.85 \\
& ISAG & $0.52^{\mathrm{a}}$ & $0.22^{\mathrm{a}}$ & $-0.43^{\mathrm{a}}$ & 0 & & & 1.45 & 3.98 \\
& ILEV & $0.44^{\mathrm{a}}$ & $0.40^{\mathrm{b}}$ & $0.32^{\mathrm{a}}$ & $-0.32^{\mathrm{a}}$ & 0 & & 2.01 & 4.89 \\
& IFSIZE & $0.23^{\mathrm{a}}$ & $0.31^{\mathrm{a}}$ & $0.23^{\mathrm{a}}$ & $0.21^{\mathrm{a}}$ & $0.04^{\mathrm{a}}$ & 0 & 1.76 & 5.01 \\
\hline South Africa & INDP & 0 & & & & & & & \\
& IFDS & $0.23^{\mathrm{a}}$ & 0 & & & & & 1.98 & 3.11 \\
& IROA & $0.11^{\mathrm{a}}$ & $0.32^{\mathrm{a}}$ & 0 & & & & 2.98 & 6.87 \\
& ISAG & $-0.34^{\mathrm{a}}$ & $0.44^{\mathrm{a}}$ & $0.23^{\mathrm{a}}$ & 0 & & & 3.21 & 2.79 \\
& ILEV & $0.12^{\mathrm{a}}$ & $0.54^{\mathrm{b}}$ & $0.12^{\mathrm{a}}$ & $0.22^{\mathrm{a}}$ & 0 & & 1.96 & 5.11 \\
& IFSIZE & $0.23^{\mathrm{a}}$ & $0.21^{\mathrm{a}}$ & $0.50^{\mathrm{b}}$ & 0.01 & $0.09^{\mathrm{a}}$ & 0 & 1.34 & 2.05 \\
\hline Overall & INDP & 0 & & & & & & & \\
& IFDS & $0.51^{\mathrm{a}}$ & 0 & & & & & 2.01 & 5.82 \\
& IROA & $0.43^{\mathrm{a}}$ & $0.32^{\mathrm{a}}$ & 0 & & & & 2.34 & 2.05 \\
& ISAG & $0.23^{\mathrm{a}}$ & $0.11^{\mathrm{a}}$ & $-0.02^{\mathrm{a}}$ & 0 & & & 2.10 & 6.98 \\
& ILEV & $0.42^{\mathrm{a}}$ & $0.40^{\mathrm{a}}$ & $0.33^{\mathrm{a}}$ & $0.06^{\mathrm{a}}$ & 0 & & 1.98 & 3.21 \\
& IFSIZE & $0.36^{\mathrm{a}}$ & $0.51^{\mathrm{b}}$ & $0.12^{\mathrm{a}}$ & $-0.10^{\mathrm{a}}$ & $0.31^{\mathrm{a}}$ & 0 & 2.91 & 5.54 \\
\hline
\end{tabular}

Note: ${ }^{\text {a }}$ represents statistical significance at $0.05 \%$

Table 5 Cross-sectional dependence test

\begin{tabular}{cccc}
\hline Variables & China & South Africa & Overall \\
\hline & CD test Value & CD test Value & CD test Value \\
INDP & $45.21^{\mathrm{b}}$ & $53.23^{\mathrm{a}}$ & $102.01^{\mathrm{a}}$ \\
lFDS & $86.34^{\mathrm{a}}$ & $78.67^{\mathrm{a}}$ & $87.21^{\mathrm{a}}$ \\
IROA & $100.12^{\mathrm{b}}$ & $111.01^{\mathrm{a}}$ & $76.45^{\mathrm{a}}$ \\
ISAG & $98.01^{\mathrm{b}}$ & $90.34^{\mathrm{b}}$ & $69.90^{\mathrm{a}}$ \\
lLEV & $78.23^{\mathrm{b}}$ & $69.01^{\mathrm{b}}$ & $80.12^{\mathrm{b}}$ \\
IFSIZE & $64.11^{\mathrm{b}}$ & $77.09^{\mathrm{a}}$ & $35.23^{\mathrm{a}}$ \\
\hline
\end{tabular}

Note: ${ }^{\mathrm{a}}$ and ${ }^{\mathrm{b}}$ represent significance level at $1 \%$ ad $5 \%$ respectively

Table 6 Homogeneity test results

\begin{tabular}{cccc}
\hline Test & China & South Africa & Overall \\
\hline $\mathrm{D}$ & $21.87^{\mathrm{a}}$ & $18.54^{\mathrm{a}}$ & $33.65^{\mathrm{a}}$ \\
$\mathrm{P}$ value & 0.00 & 0.00 & 0.00 \\
$\mathrm{D}$ adj & $25.98^{\mathrm{a}}$ & $16.78^{\mathrm{b}}$ & $28.98^{\mathrm{a}}$ \\
$\mathrm{P}$ value & 0.00 & 0.00 & 0.00 \\
\hline
\end{tabular}

Note: ${ }^{\mathrm{a}}$ and ${ }^{\mathrm{b}}$ represent significance level at $1 \%$ ad $5 \%$ respectively

Table 7 ADF Panel Unit root Test

\begin{tabular}{ccccccc}
\hline & \multicolumn{2}{c}{ China } & \multicolumn{2}{c}{ South Africa } & \multicolumn{2}{c}{ Overall } \\
\hline & $\mathrm{I}(0)$ & $\mathrm{I}(1)$ & $\mathrm{I}(0)$ & $\mathrm{I}(1)$ & $\mathrm{I}(0)$ & $\mathrm{I}(1)$ \\
INDP & -2.87 & $-5.87^{\mathrm{a}}$ & $-1.77^{\mathrm{a}}$ & $-3.64^{\mathrm{a}}$ & -4.98 & $-7.98^{\mathrm{a}}$ \\
lFDS & -1.34 & $-3.21^{\mathrm{a}}$ & -1.81 & $-2.98^{\mathrm{a}}$ & -2.21 & $-4.43^{\mathrm{b}}$ \\
IROA & -4.53 & $-8.44^{\mathrm{a}}$ & -2.56 & $-5.46^{\mathrm{a}}$ & -4.23 & $-6.34^{\mathrm{a}}$ \\
ISAG & $-1.89^{\mathrm{a}}$ & $-4.32^{\mathrm{a}}$ & -2.09 & $-3.32^{\mathrm{b}}$ & -1.99 & $-5.64^{\mathrm{a}}$ \\
ILEV & -3.24 & $-5.45^{\mathrm{a}}$ & -3.23 & $-6.53^{\mathrm{b}}$ & -2.22 & $-4.78^{\mathrm{a}}$ \\
lFSIZE & $-2.12^{\mathrm{b}}$ & $-4.45^{\mathrm{a}}$ & $-2.76^{\mathrm{a}}$ & $-5.45^{\mathrm{a}}$ & -3.33 & $-4.56^{\mathrm{a}}$ \\
\hline
\end{tabular}

Note: ${ }^{\mathrm{a}}$ and ${ }^{\mathrm{b}}$ represent significance level at $1 \%$ ad $5 \%$ respectively 
Table 8 PMG/ARDL long-run Estimation

\begin{tabular}{cccccccc}
\hline & \multicolumn{2}{c}{ China } & \multicolumn{2}{c}{ South Africa } & \multicolumn{2}{c}{ Overall } \\
\hline Variables & Coef. & Prob. & Coef. & Prob. & Coef. & Prob. \\
IFDS & -0.05 & $0.00^{\mathrm{a}}$ & -0.32 & $0.00^{\mathrm{a}}$ & -0.23 & $0.05^{\mathrm{b}}$ \\
IROA & 0.07 & $0.03^{\mathrm{a}}$ & 0.09 & $0.00^{\mathrm{a}}$ & 0.11 & $0.00^{\mathrm{a}}$ \\
ISAG & 0.12 & $0.01^{\mathrm{a}}$ & 0.03 & $0.04^{\mathrm{a}}$ & -0.07 & 0.08 \\
ILEV & -0.93 & 0.06 & -0.01 & 0.07 & -0.23 & 0.11 \\
IFSIZE & 0.04 & $0.02^{\mathrm{a}}$ & 0.11 & $0.03^{\mathrm{a}}$ & 0.21 & $0.03^{\mathrm{a}}$ \\
ECT & -0.31 & $0.01^{\mathrm{a}}$ & -0.53 & $0.00^{\mathrm{a}}$ & -0.20 & $0.04^{\mathrm{a}}$ \\
Hausman test & 4.53 & 0.23 & 3.85 & 0.10 & 5.12 & 0.31 \\
CD-test & 1.98 & $0.00^{\mathrm{a}}$ & 2.01 & $0.00^{\mathrm{a}}$ & 2.45 & $0.02^{\mathrm{a}}$ \\
\hline
\end{tabular}

Note: ${ }^{\mathrm{a}}$ and ${ }^{\mathrm{b}}$ represent significance level at $1 \%$ ad $5 \%$ respectively

Table 9 Robustness Test

\begin{tabular}{ccccccc}
\hline & \multicolumn{2}{c}{ China } & \multicolumn{2}{c}{ South Africa } & \multicolumn{2}{c}{ Overall } \\
\cline { 2 - 7 } Variables & Coef. & Prob. & Coef. & Prob. & Coef. & Prob. \\
\hline$C C E P M G / C S-A R D L$ & Long-run output & & \\
\hline lFDS & -0.21 & $0.00^{\mathrm{a}}$ & -0.54 & $0.03^{\mathrm{a}}$ & -0.27 & $0.01^{\mathrm{a}}$ \\
IROA & 0.02 & $0.01^{\mathrm{a}}$ & 0.05 & $0.00^{\mathrm{a}}$ & 0.81 & $0.04^{\mathrm{a}}$ \\
ISAG & 0.05 & $0.04^{\mathrm{a}}$ & 0.07 & $0.05^{\mathrm{a}}$ & -0.02 & 0.09 \\
lLEV & -0.81 & 0.07 & -0.65 & $0.04^{\mathrm{a}}$ & -0.43 & 0.17 \\
IFSIZE & 0.21 & $0.00^{\mathrm{a}}$ & 0.18 & $0.01^{\mathrm{a}}$ & 0.42 & $0.00^{\mathrm{a}}$ \\
ECT & -0.43 & $0.00^{\mathrm{a}}$ & -0.63 & $0.00^{\mathrm{a}}$ & -0.39 & $0.00^{\mathrm{a}}$ \\
CD-test & -3.02 & 0.23 & -2.89 & 0.12 & -2.62 & 0.10 \\
\hline MG-ARDL & Lon-run output & & & & \\
\hline lFDS & -0.16 & $0.00^{\mathrm{a}}$ & -0.45 & $0.01^{\mathrm{a}}$ & -0.11 & $0.02^{\mathrm{a}}$ \\
lROA & 0.04 & $0.00^{\mathrm{a}}$ & 0.03 & $0.01^{\mathrm{a}}$ & 0.64 & $0.04^{\mathrm{a}}$ \\
ISAG & 0.03 & $0.00^{\mathrm{a}}$ & 0.13 & 0.06 & 0.22 & 0.07 \\
lLEV & -0.74 & 0.12 & -0.43 & 0.02 & -0.21 & 0.09 \\
IFSIZE & 0.19 & $0.01^{\mathrm{a}}$ & 0.12 & $0.00^{\mathrm{a}}$ & 0.37 & $0.00^{\mathrm{a}}$ \\
ECT & -0.22 & $0.00^{\mathrm{a}}$ & -0.35 & $0.00^{\mathrm{a}}$ & -0.18 & $0.00^{\mathrm{a}}$ \\
CD-test & -4.87 & $0.00^{\mathrm{a}}$ & 3.07 & $0.00^{\mathrm{a}}$ & 3.98 & $0.00^{\mathrm{a}}$ \\
\hline
\end{tabular}

Note: ${ }^{\mathrm{a}}$ and ${ }^{\mathrm{b}}$ represent significance level at $1 \%$ ad $5 \%$ respectively

Table 10 Dumitrescu-Hurlin Panel Causality test outcome

\begin{tabular}{|c|c|c|c|}
\hline Null hypothesis & China & South Africa & Overall \\
\hline IFDS $®$ INDP & $0.45\left(0.00^{\mathrm{a}}\right)$ & $1.34\left(0.00^{\mathrm{a}}\right)$ & $1.57\left(0.02^{\mathrm{a}}\right)$ \\
\hline INDP $₫ \quad$ lFDS & $0.65(0$ & $0.55\left(0.05^{\mathrm{b}}\right)$ & 1.32 \\
\hline IROA®INDP & & & 08) \\
\hline INDP & 0.78 & $0.63\left(0.02^{\mathrm{a}}\right)$ & 1.45 \\
\hline ISAG®INDP & & & 1.45 \\
\hline INDP $® 1 S$ & & & 0.8 \\
\hline lLEV®IN & ( & & 1.1 \\
\hline INDP ®lLEV & $0.19(0.11)$ & & 0.88 \\
\hline IFSIZE®INDP & $1.21\left(0.01^{\mathrm{a}}\right)$ & $0.98(0.06)$ & $1.13(0.12)$ \\
\hline INDP $®$ IFSIZE & $0.87\left(0.00^{\mathrm{a}}\right)$ & $1.20(0.31)$ & $0.77(0.08)$ \\
\hline
\end{tabular}

Note: ${ }^{\mathrm{a}}$ and ${ }^{\mathrm{b}}$ represent significance level at $1 \%$ ad $5 \%$ respectively 